\title{
Evaluation of User Experience Information Systems Using Heuristic Evaluation (Case Study of STMIK Amik Riau Student Portal)
}

\author{
Heru Satria Surya ${ }^{1}$, Benino Giordiola Millenio ${ }^{2}$, Silvyana Dwi Putri ${ }^{3}$, Junadhi ${ }^{4}$ \\ 1,3 Teknologi Informasi, Sekolah Tinggi Manajemen Informatika dan Komputer Amik Riau
}

\begin{tabular}{l} 
Article Info \\
\hline Article history: \\
Received 11 11, 2021 \\
Revised 12 10, 2021 \\
Accepted 10 14, 2021 \\
\hline
\end{tabular}

\section{Keywords:}

Information Systems

User Experience

Usability

Heuristics

Evaluation

\begin{abstract}
The academic information system is an important system to supports lecture activities. Is used by almost all elements in the university, both students, lecturers, staff and leaders. This research uses Heuristic Evaluation as an inference method to assess the components of learnability, efficiency, memorability, errors, and satisfaction. for various cases, such as designing academic and corporate websites with reference to these problems, it is necessary to evaluate the usability of STMIK Amik Riau information system. STMIK Amik Riau implements an integrated information system to support fast and real-time information management processes of STMIK Amik Riau information system includes various services such as E-KRS, E-KTM, EEDOM, and other information. The aim is to identify problems related to the usability of the website. The data collection method in this research was carried out using questionnaire, containing a list of questions distributed via google form to respondents, its about 100 students of STMIK Amik Riau. Based on the analysis conducted using the Heuristic Evaluation method, the evaluation results of STMIK Amik Riau web portal have met the usability criteria with an average of $78.71915 \%$ where $\mathrm{P}>60 \%$ and provides user satisfaction in accessing STMIK Amik Riau web portal. STMIK Amik Riau's web interface design is quite good. These results are based on the results of Likert scale score which states that the respondents agree.
\end{abstract}

This is an open access article under the CC BY-SA license.

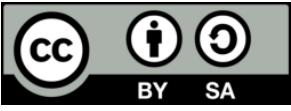

\section{Corresponding Author:}

Heru Satria Surya, Benino Giordiola Millenio, Silvyana Dwi Putri

Teknologi Informasi, Sekolah Tinggi Manajemen Informatika dan Komputer Amik Riau

Jl. Purwodadi Indah, Sidomulyo Barat., Pekanbaru

Email: herusatriasuryaa@gmail.com, beninogiordiola03@gmail.com, silvyanadp2000@gmail.com

(C) The Author(s) 2021

\section{Introduction}

Academic information system is a collection of integrated systems to achieve the goal of processing data into information needed by users related to academic activities [1]. The academic information system is an important system to supports lecture activities because it is used by almost all elements in the university, both students, lecturers, staff and leaders [2]. Adapting to the newest technology, STMIK Amik Riau implements an integrated information system to support fast and real-time information management processes, STMIK Amik Riau information system or usually called SAR includes various services such as E-KRS, E-KTM, E-EDOM, correspondence, alumni tracer, online registration, E-learning, E-thesis, library, SATIN journal, LPPM, and laboratories as well as other information.

User Experience is a person's understanding of the use of a product, system or service [3]. In user experience there is an assessment of the user's understanding, satisfaction, and comfort will use a product, 
system or service. In other words, in the user experience, it can be seen how users get convenience and efficiency in interacting with a system. There are 4 interdependent user experience elements, including:

1. Branding, consisting of all aspects of design and aesthetics included in the website

2. Usability, includes requirements for components, features, navigation and website accessibility

3. Functionality, it's the processes and techniques of work procedure in a system.

4. Content, it contains the information and structure presented, such as images, multimedia and text

Usability is usage of product can be used by users in achieving goals including aspects of effectiveness, efficiency, and satisfaction in certain contexts [4]. User experience is prioritized in interacting with the system or website to operated easily and quickly [5]. The inconsistency of some displays also affects the user experience in accessing the system. A system must be consistent to prevent a non-standard impression on a system [6]. One of the important points in building an information system is related to design of interface designs to provide convenience for system users [7].

The higher of interface design value on a system, the higher of benefits of the system for users [8]. The quality and acceptance of product depends on the ease of use of product, it causes the users more concerned with the ease of product used [9]. It related to the level of usability of a good system. The system can be said a high level of usability if the users can get what they need and understand the system [8]. The level of usability determines the profitability of system, acceptability of users and durablility of usage [10].

Currently, in the development and implementation of information systems and software carried out by many parties, usability testing is rarely to conducted [10]. Usability focuses on the attributes of the system and efforts to avoid errors or usability problems [11]. Usability describes the usage of product can be used by users to achieve certain goals by measuring factors of effectiveness, efficiency and user satisfaction [12]. The important factors of usability include user habits or behavior in accessing the system. Many users cannot accept a bad system design and take the time to learn a system. In other words, users really want to immediately understand what the system presents so that usability measurements need to be carried out on an application or information system [7]. In thus result, a system needs to be evaluated according to standards to find out how the system is. The most relevant evaluation is to determine the interface design standards and the level of usability of the system. This can be done by measuring the system using usability methods, it is Heuristic Evaluation [13] .

Heuristic Evaluation is a usability evaluation method to improve a design effectively by using a set of related heuristics [11], [14]. It aim to identify problems related to website usability [11], [15], [14]. Heuristic Evaluation has the advantage of testing that provides fast and relatively inexpensive feedback and can be used in conjunction with other usability evaluation methods [11]. A set of heuristics in Heuristic Evaluation includes usability aspects used as guidelines for evaluating information systems [11]. The concept in Heuristic Evaluation method has 10 principles, namely visibility of system status, match between system and real world, user control and freedom, consistency and standards, help user recognize diagnose and recover from errors, error prevention, recognition rather than recall, flexibility and efficiency of use, aesthetic and minimalist design, and help and document [10].

This research uses Heuristic Evaluation as an inference method to assess the components of learnability, efficiency, memorability, errors, and satisfaction [12]. Previous researchers have widely used Heuristic Evaluation for various cases, such as designing academic websites [2], [7], [11], [14], [17] and companies [18], [19] and mobile applications [20], [21], [22], [23]. A research of STMIK Amik Riau information system needs to be carried out to find out whether users feel learnability, efficiency, memorability, errors, and satisfaction toward the existing information system. It is hoped that if users feel the benefits or usefulness of STMIK Amik Riau information system, it will be continued to access the site. The purpose of this research was to determine whether STMIK Amik Riau students felt the benefits or usefulness of STMIK Amik Riau information system. With reference to these problems, it is necessary to evaluate the usability of STMIK Amik Riau information system which is expected to be used as a reference for the system development team in making improvements to have high level of usability and achieves user satisfaction.

\section{Research Methodology}

A. Relevan Research

In this research, to solve the problems it was conducted literature study as referenc to support data in problem solving. There are several theories, such as heuristic evaluation and usability. In addition to literature studies, studies related to similar previous studies were also carried out in order to be used

Jurnal Teknologi dan Open Source, Vol. 4, No. 2, December 2021: 180 - 188 
as reference for this research. One of them, the research conducted by Dina Caesaron (2015). In her research, heuristic evaluation method was used. The evaluation carried out on the student portal website in general, the interface design on the portal is quite good from the results of the heuristic evaluation. There are several things still need to be improved to ease of usage becomes better [6]. Then, Ricky Firmansyah's research (2016) was conducted to determine the usability of the interface design of MyIndihome application version 5.1 on the android platform using heuristic evaluation. The research found MyIndihome application interface design has been able to provide comfort for users in general but application improvements can still be made to ease of usage and accuracy of information [24]. Then, the research by Suci Indrawati Irwan, Imas Sukaesih Sitanggang, and B. Mustafa (2015) aims to evaluate the usability of the Management Information System for Receiving Deposit Collections at the National Library of Republic of Indonesia based on the Heuristic Evaluation approach and provide recommendations on usability aspects to make system improvements. The results of the recommendations from this research can contribute ideas for the leadership of the National Library of Indonesia to make decisions in developing and improving the management information system for receiving deposit collections at the National Library of Indonesia [25]. It can be taken from the three research that the Heuristic Evaluation method is one method can be used to identify and explore usability problems in a system being studied.

B. Observation

Observations directly conducted on the object of research, it is STMIK Amik Riau Information System. It can be accessed at sar.ac.id link. In this information system, observations focus on interfaces related to usability of the system.

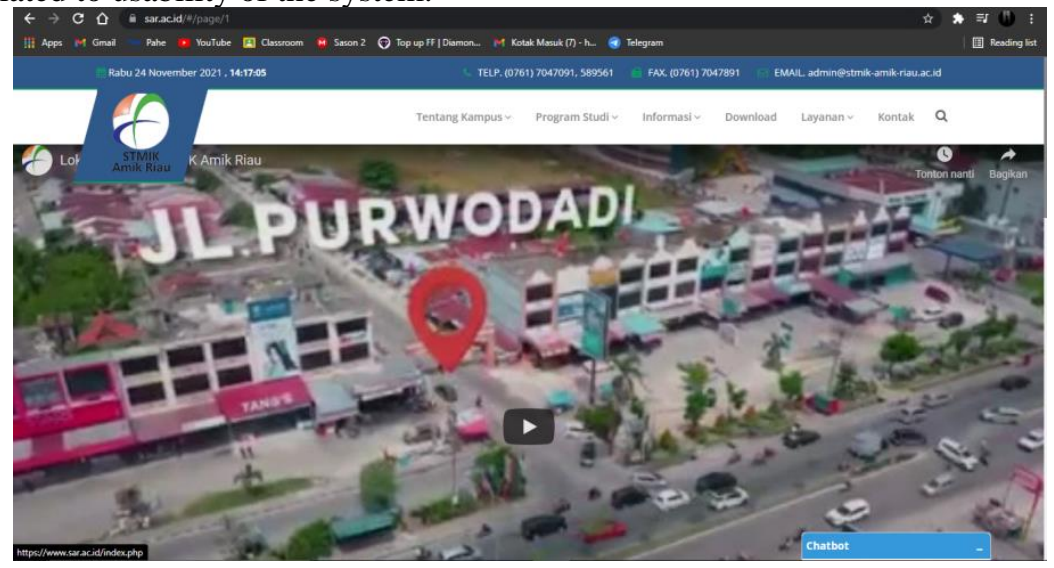

Figure 1. STMIK Amik Riau Information System (sar.ac.id)

C. Problem Identification

The problems found in this research will be made problem formulation. The formulation of the problem in this research is how the user experience of STMIK Amik Riau information system uses the Heuristic Evaluation method.

D. Data Collection

At this phase, there are 3 activities, namely determining respondents, distributing questionnaires, and processing data. Respondents in this research were active students at STMIK Amik Riau which consisted of Informatics Engineering, Information Technology and Information Systems study programs. To calculate the minimum number of samples required use the Lemeshow formula as follows:

$$
n=\frac{Z^{2} \times P(1-P)}{d^{2}}
$$

Information :

$\mathrm{n}=$ number of samples

$\mathrm{Z}=\mathrm{Z}$ score at $95 \%$ confidence $=1.96$

$\mathrm{P}=$ maximum estimate 
$\mathrm{d}=$ alpha $(0,10)$ or sampling error $=10 \%$

The number of samples according to Lemeshow's formula is 96.04. In this research, at least 97 people must take data from sample. It was determined to take questionnaire data 100 people. The distribution of the questionnaires uses random sampling technique, namely the distribution is conducted to all members of the population randomly without regard to the existing strata in the population [26]. The distribution of the questionnaire was carried out using Google Forms. The questionnaire in this research was designed based on 10 principles, namely visibility of system status, match between system and real world, user control and freedom, consistency and standards, help users recognize diagnose and recover from errors, error prevention, recognition rather than recall, flexibility and efficiency. of use, aesthetic and minimalist design, and help and document [13] to determine the quality of the system based on the ease and convenience of system users.

E. Dokumentation

The last phase is to document the results obtained in the previous phase into a report and prepare for publication.

\section{Result and Finding}

The method of data collection in this research was carried out using questionnaire, containing list of questions distributed via google form to respondents, STMIK Amik Riau students. The answer to the questionnaire given is to choose an answer on scale of 1-5 which is used to measure the views and attitudes of respondents towards the answer. The measurement scale used is Likert scale, divided into a rating score scale between 1-5, where the score of 1 for respondents' answers Strongly Disagree up to score of 5 for answers Strongly Agree. The rating scale is presented in Table 1.

Table 1. Research Scale

\begin{tabular}{ccc}
\hline Question & Abbreviation & Score \\
\hline Strongly Disagree & STS & 1 \\
Disagree & TS & 2 \\
Neutral & N & 3 \\
Agree & S & 4 \\
Strongly Agree & SS & 5 \\
\hline
\end{tabular}

In calculating the eligibility criteria, it is done by multiplying the value of the assessment by the number of assessment scores by the number of indicators measured in accordance with the formula for Percentage of eligibility for each aspect $(\%)=$

$$
\frac{\sum \text { earned score }}{\sum \text { maximum score }} \times 100 \%
$$

The results of the multiplication will be analyzed into the distribution of values and percentages with rating scale according to Table 2 .

Table 2. Category of Eligibility Percentage

\begin{tabular}{cc}
\hline Percentage & Category \\
\hline $81 \%-100 \%$ & Best \\
$61 \%-80 \%$ & Better \\
$41 \%-60 \%$ & Good \\
$21 \%-40 \%$ & Worse \\
$0 \%-20 \%$ & Worst \\
\hline
\end{tabular}

The calculation of the percentage of respondents' answers is done through the distribution of frequency and percentage using the formula:

Jurnal Teknologi dan Open Source, Vol. 4, No. 2, December 2021: 180 - 188 
Information :

$$
\mathrm{P}=\frac{\mathrm{f}}{\mathrm{N}} \times 100 \%
$$

$\mathrm{P}=$ Percentage

$\mathrm{F}=$ Data Frequency

$\mathrm{N}=$ Number of samples processed

Table 3. Questionnaire Processing Results

\begin{tabular}{|c|c|c|c|c|c|c|c|}
\hline \multirow{3}{*}{ Code } & \multicolumn{5}{|c|}{ Likert Scale } & \multirow{3}{*}{ Total } & \multirow{3}{*}{$\begin{array}{c}\text { PERCEN } \\
\text { TAGE } \\
\text { INDEX }\end{array}$} \\
\hline & 1 & 2 & 3 & 4 & 5 & & \\
\hline & STS & TS & $\mathrm{N}$ & S & SS & & \\
\hline A 1.1 & 1 & 2 & 84 & 164 & 145 & 396 & 79,2 \\
\hline A 1.2 & 0 & 12 & 69 & 212 & 90 & 383 & 76,6 \\
\hline A 1.3 & 1 & 10 & 78 & 188 & 105 & 382 & 76,4 \\
\hline A 1.4 & 0 & 6 & 78 & 200 & 105 & 389 & 77,8 \\
\hline A 1.5 & 0 & 4 & 66 & 200 & 130 & 400 & 80 \\
\hline $\mathrm{A} 2.1$ & 0 & 6 & 81 & 196 & 105 & 388 & 77,6 \\
\hline $\mathrm{A} 2.2$ & 0 & 2 & 72 & 208 & 115 & 397 & 79,4 \\
\hline A 2.3 & 0 & 2 & 81 & 168 & 150 & 401 & 80,2 \\
\hline A 2.4 & 0 & 4 & 111 & 164 & 100 & 379 & 75,8 \\
\hline A 2.5 & 0 & 2 & 96 & 152 & 145 & 395 & 79 \\
\hline A 3.1 & 0 & 4 & 78 & 144 & 180 & 406 & 81,2 \\
\hline A 3.2 & 0 & 2 & 66 & 196 & 140 & 404 & 80,8 \\
\hline A 3.3 & 0 & 6 & 69 & 180 & 145 & 400 & 80 \\
\hline A 3.4 & 0 & 0 & 75 & 196 & 130 & 401 & 80,2 \\
\hline A 3.5 & 0 & 4 & 75 & 184 & 135 & 398 & 79,6 \\
\hline A 4.1 & 0 & 4 & 99 & 132 & 160 & 395 & 79 \\
\hline A 4.2 & 0 & 2 & 63 & 220 & 115 & 400 & 80 \\
\hline A 4.3 & 0 & 0 & 93 & 176 & 125 & 394 & 78,8 \\
\hline A 4.4 & 0 & 8 & 81 & 184 & 115 & 388 & 77,6 \\
\hline A 4.5 & 0 & 6 & 99 & 160 & 120 & 385 & 77 \\
\hline A5.1 & 0 & 4 & 84 & 172 & 135 & 395 & 79 \\
\hline A5.2 & 1 & 4 & 69 & 212 & 105 & 391 & 78,2 \\
\hline A5.3 & 2 & 2 & 57 & 184 & 160 & 405 & 81 \\
\hline A5.4 & 0 & 2 & 81 & 192 & 120 & 395 & 79 \\
\hline A5.5 & 0 & 4 & 78 & 188 & 125 & 395 & 79 \\
\hline A6.1 & 0 & 2 & 99 & 156 & 135 & 392 & 78,4 \\
\hline A6.2 & 0 & 2 & 81 & 192 & 120 & 395 & 79 \\
\hline A6.3 & 0 & 4 & 99 & 168 & 115 & 386 & 77,2 \\
\hline A7.1 & 0 & 0 & 75 & 176 & 155 & 406 & 81,2 \\
\hline A7.2 & 0 & 8 & 84 & 188 & 105 & 385 & 77 \\
\hline A7.3 & 1 & 4 & 93 & 164 & 125 & 387 & 77,4 \\
\hline A7.4 & 2 & 2 & 78 & 180 & 130 & 392 & 78,4 \\
\hline A7.5 & 1 & 4 & 81 & 184 & 120 & 390 & 78 \\
\hline A8.1 & 0 & 6 & 81 & 152 & 160 & 399 & 79,8 \\
\hline A 8.2 & 0 & 8 & 66 & 176 & 150 & 400 & 80 \\
\hline
\end{tabular}




\begin{tabular}{lccccccc} 
A8.3 & 0 & 10 & 75 & 176 & 130 & 391 & $\mathbf{7 8 , 2}$ \\
A9.1 & 0 & 2 & 60 & 192 & 155 & 409 & $\mathbf{8 1 , 8}$ \\
A9.2 & 1 & 0 & 102 & 156 & 130 & 389 & $\mathbf{7 7 , 8}$ \\
A9.3 & 1 & 0 & 87 & 164 & 145 & 397 & $\mathbf{7 9 , 4}$ \\
A9.4 & 1 & 0 & 90 & 180 & 120 & 391 & $\mathbf{7 8 , 2}$ \\
A9.5 & 1 & 4 & 93 & 160 & 130 & 388 & $\mathbf{7 7 , 6}$ \\
A10.1 & 1 & 6 & 78 & 156 & 155 & 396 & $\mathbf{7 9 , 2}$ \\
A10.2 & 1 & 4 & 87 & 176 & 125 & 393 & $\mathbf{7 8 , 6}$ \\
A10.3 & 2 & 10 & 84 & 148 & 140 & 384 & $\mathbf{7 6 , 8}$ \\
A10.4 & 1 & 8 & 117 & 120 & 135 & 381 & $\mathbf{7 6 , 2}$ \\
A10.5 & 1 & 6 & 81 & 176 & 125 & 389 & $\mathbf{7 7 , 8}$ \\
A10.6 & 0 & 4 & 84 & 164 & 145 & 397 & $\mathbf{7 9 , 4}$ \\
RATA- & $\mathbf{0 , 4 0 4 2 5 5}$ & $\mathbf{4 , 1 7 0 2 1 3}$ & $\mathbf{8 2 , 0 8 5 1 1}$ & $\mathbf{1 7 6 , 0 8 5 1}$ & $\mathbf{1 3 0 , 8 5 1 1}$ & $\mathbf{3 9 3 , 5 9 5 7}$ & $\mathbf{7 8 , 7 1 9 1 5}$ \\
RATA & & & & & & & \\
\hline
\end{tabular}

Based on the analysis conducted using the Heuristic Evaluation method, the frequency of categories is obtained as follows:

1) Visibility of System Status

The system should always keep users informed through feedback messages in the right time. Viewing from table 3, the results of processing the questionnaire on the Visibility of System Status variable obtained the results of the assessment on A1.1 indicator, percentage of $79.2 \%$ was obtained, A1.2 indicator obtained percentage of 76.6\%, A1.3 indicator obtained percentage of 76.4\%, A1 indicator .4 obtained percentage of $77.8 \%$ and indicator A1.5 obtained percentage of $80 \%$. From these indicators, the average percentage is $78 \%$. Based on the average value of the percentage, Visibility of System Status variable has a good usability level.

2) Match Between System and The Real World

Based on the results of data analysis in Table 3, for Match Between System and The Real World variable, it can be seen that A2.1 indicator obtained percentage of 77.6\%, A2.2 indicator obtained percentage of $79.4 \%$, A2.3 indicator obtained percentage of $80.2 \%$, indicator A2.4 obtained percentage of $75.8 \%$, and indicator A2.5 obtained percentage of 79\%. From these indicators obtained average percentage of $78.4 \%$. Based on the average value of the percentage, Match Between System and The Real World variable has a good usability level.

3) User Control and Freedom

Based on the results of data analysis in Table VIII. For the User Control and Freedom variable, it can be seen that A3.1 indicator obtained percentage of 81.2\%, and A3.2 indicator obtained percentage of $80.8 \%$, from A3.3 indicator percentage of $80 \%$ was obtained, from A3.4 indicator the percentage was $80.2 \%$, and the indicator A3.5 obtained percentage of 79.6\%. From these indicators, the average percentage is $80.36 \%$. Based on the average value of the percentage, User Control and Freedom variable has a good usability level.

4) Consistency and Standards

Based on the results of data analysis in Table 3. For User Consistency and Standards variable, it can be seen that A4.1 indicator obtained percentage of 79\%, A4.2 indicator obtained percentage of $80 \%$, A4.3 indicator obtained percentage of $78.8 \%$, A4 indicator. 4 obtained percentage of $77.6 \%$ and indicator A4.5 obtained percentage of $77 \%$. From these indicators, the average percentage is $78.48 \%$. Based on the average value of the percentage, User Consistency and Standards variable has a good usability level.

5)Help Users Recognize, Diagnose and Recover from Errors 
Based on the results of data analysis in Table 3. For Help Users Recognize, Diagnose and Recover from Errors variable, it can be seen that A5.1 indicator obtained percentage of 79\%, A5.2 indicator obtained percentage of $78.2 \%$, A5.3 indicator obtained percentage of $81 \%$, indicator A5.4 obtained percentage of $79 \%$, and indicator A5.5 obtained percentage of 79\%. From these indicators obtained an average percentage of $79.24 \%$. Based on the average value of the percentage, Help Users Recognize, Diagnose and Recover from Errors variable has a good usability level.

6) Error Prevention

Based on the results of data analysis in Table 3. For Error Prevention variable, it can be seen that A6.1 indicator obtained percentage of 78.4\%, A6.2 indicator obtained percentage of 79\%, and A6.3 indicator obtained percentage of $77.2 \%$. From these indicators, the average percentage is $78.2 \%$. Based on the average value of the percentage, Error Prevention variable has a good usability level.

7) Recognition Rather Than Recall

Based on the results of data analysis in Table 3. For Recognition Rather Than Recall variable, it can be seen that A7.1 indicator obtained percentage of $81.2 \%$, A7.2 indicator obtained percentage of $77 \%$, A7.3 indicator obtained percentage of $77.4 \%$, A7 indicator. 4 obtained percentage of $78.4 \%$, and indicator A7.5 obtained percentage of $78 \%$. From these indicators obtained an average percentage of $78.4 \%$. Based on the average value of the percentage, Recognition Rather Than Recall variable has a good usability level.

8) Flexibility and Efficinency of Use

Based on the results of data analysis in Table 3. With respect to the Flexibility and Efficiency of Use variable, it can be seen that A8.1 indicator obtained percentage of 79.8\%, A8.2 indicator obtained percentage of $80 \%$, and A8.3 indicator obtained percentage of $78.2 \%$. From these indicators, the average percentage is $79.33 \%$. Based on the average value of the percentage, Flexibility and Efficiency of Use variable has a good usability level.

9) Aesthetic and Minimalist Design

Based on the results of data analysis in Table 3. For Aesthetic and Minimalist Design variable, it can be seen that A9.1 indicator obtained percentage of $81.8 \%$, A9.2 indicator obtained percentage of $77.8 \%$, A9.3 indicator obtained percentage of 79.4\%, A9 indicator. 4 obtained percentage of $78.2 \%$, and A9.5 indicator obtained percentage of $77.6 \%$. From these indicators, the average percentage is $78.96 \%$. Based on the average value of the percentage, Aesthetic and Minimalist Design variable has a good usability level.

10)Help and Documentation

Based on the results of data analysis in Table 3. For Help and Documentation variable, it can be seen that A10.1 indicator obtained percentage of $79.2 \%$, A10.2 indicator obtained percentage of $78.6 \%$, A10.3 indicator obtained percentage of $76.8 \%$, A10.4 indicator obtained percentage of $76.2 \%$, indicator A10.5 obtained percentage of $77.8 \%$, and indicator A10.6 obtained percentage of $78 \%$. From these indicators, the average percentage is $78 \%$. Based on the average value of the percentage, Help and Documentation variable has a good usability level.

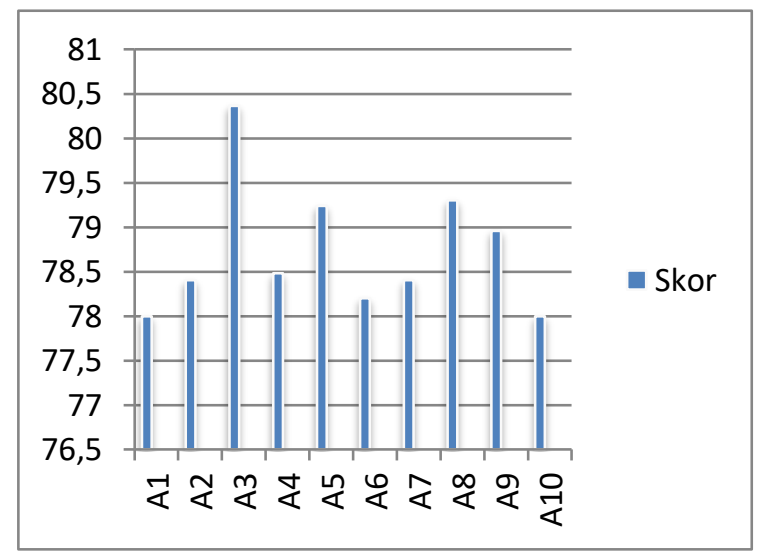

Jurnal Teknologi dan Open Source, Vol. 4, No. 2, December 2021: 180 - 188 
Figure 2. Average of Heuristic Evaluation Variable

Based on the results of the analysis in Figure 2. the indicator A1 (Visibility of System Status) obtained average percentage of 78\%, the indicator A2 (Match Between System and The Real World) obtained average percentage of $78.4 \%$, the indicator A3 (User Control and Freedom) obtained average percentage of $80.36 \%$, the ondicator A4 (Consistency and Standards) obtained average percentage of $78.48 \%$, the indicator A5 (Help Users Recognize, Diagnose and Recover from Errors) obtained average percentage of $79.24 \%$, the indicator A6 (Error Prevention) obtained average percentage of $78.2 \%$, the indicator A7 (Recognition Rather Than Recall) obtained average percentage of 78.4\%, the indicator A8 (Flexibility and Efficiency of Use) obtained average percentage of $79.33 \%$, the indicator A9 (Aesthetic and Minimalist Design) obtained average percentage of 78.96\%, and the indicator A10 obtained average percentage of $78 \%$. Where of all indicators have a good level of usability.

It can be concluded that each assessment of the evaluation results of STMIK Amik Riau Information System has the greatest value among the variable indicators, namely User Control and Freedom with an overall score of $80.36 \%$. Thus STMIK Amik Riau Information System has the freedom for users to carry out orders according to their respective controls very well.

\section{Conclusion}

Based on the results of the evaluation and analysis of research data, it can be concluded that the results of the evaluation of STMIK Amik Riau web portal have met usability criteria, the result with average of $78.71915 \%$ where $\mathrm{P}>60 \%$ has a good usability level and provides satisfaction users in accessing STMIK Amik Riau web portal. STMIK Amik Riau's web interface design is quite good. These results are based on the results of Likert scale score, it states that the respondents agree.

\section{References}

[1] T. Sutabri, "Konsep Sistem Informasi," J. Adm. Pendidik. UPI, vol. 3, no. 1, p. 248, 2012.

[2] W. Dimuksa, P. D. Abda'u, and J. Karaman, "Usability Evaluation pada Website STKIP PGRI Pacitan,” Semnasteknomedia Online, vol. 4, no. 1, pp. 115-120, 2016, [Online]. Available: https://ojs.amikom.ac.id/index.php/semnasteknomedia/article/view/1317/1241.

[3] M. B. Wiryawan, "User Experience (Ux) sebagai Bagian dari Pemikiran Desain dalam Pendidikan Tinggi Desain Komunikasi Visual," Humaniora, vol. 2, no. 2, p. 1158, 2011, doi: 10.21512/humaniora.v2i2.3166.

[4] A. Kurniawan, R. I. Rokhmawati, and A. Rachmadi, "Evaluasi User Experience dengan Metode Heuristic Evaluation dan Persona (Studi pada : Situs Web Dalang Ki Purbo Asmoro)," J. Pengemb. Teknol. Inf. dan Ilmu Komput., vol. 2, no. 8, pp. 2918-2926, 2018, [Online]. Available: http://j-ptiik.ub.ac.id.

[5] D. I. Sensuse and S. H. Prayoga, “Analisis Usability Pada Aplikasi Berbasis Web Dengan Mengadopsi Model Kepuasan Pengguna (User Satisfaction),” J. Sist. Inf., vol. 6, no. 1, p. 70, 2012, doi: 10.21609/jsi.v6i1.278.

[6] D. Caesaron, "Evaluasi Heuristic Desain Antar Muka (Interface) Portal Mahasiswa (Studi Kasus Portal Mahasiswa Universitas X),” J. METRIS, vol. 16, no. 1, pp. 9-14, 2015, [Online]. Available:

http://ojs.atmajaya.ac.id/index.php/metris/article/view/288/241\%0Ahttp://ojs.atmajaya.ac.id/index .php/metris/article/view/288.

[7] P. Krisnayani, K. R. Arthana, and G. M. Darmawiguna, "Analisa Usability Pada Website UNDIKSHA Dengan Menggunakan Metode Heuristic Evaluation,” J. Pendidik. Teknol. dan Kejuru., vol. 16, no. 1, p. 98, 2019, doi: 10.23887/jptk-undiksha.v16i1.18171.

[8] S. K. Hendra and S. K. Yulyani Arifin, "Web-based Usability Measurement for Student Grading Information System,” Procedia Comput. Sci., vol. 135, pp. 238-247, 2018, doi: 10.1016/j.procs.2018.08.171.

[9] E. Kiliç Delice and Z. Güngör, "The usability analysis with heuristic evaluation and analytic hierarchy process,” Int. J. Ind. Ergon., vol. 39, no. 6, pp. 934-939, 2009, doi: 10.1016/j.ergon.2009.08.005.

[10] K. Aelani and Falahah, "Pengukuran Usability Sistem Menggunakan Use Questionnaire," Semin. Nas. Apl. Teknol. Inf. 2012 (SNATI 2012), vol. 2012, no. Snati, pp. 15-16, 2012.

[11] B. A. Mustikaningtyas, M. C. Saputra, and A. Pinandito, "Analisis Usability Pada Website

Jurnal Teknologi dan Open Source, Vol. 4, No. 2, December 2021: 180 - 188 
Universitas Brawijaya Dengan Heuristic Evaluation,” J. Teknol. Inf. dan Ilmu Komput., vol. 3, no. 3, p. 188, 2016, doi: 10.25126/jtiik.201633194.

[12] M. Huda, "EVALUASI USABILITY WEBSITE STIE PUTRA BANGSA SEBAGAI MEDIA INFORMASI PERGURUAN TINGGI Rumusan Masalah Batasan Masalah di Evaluasi usability kepada mahasiswa sebagai salah satu pengguna dari website Sekolah Tinggi Ilmu Ekonomi Putra Bangsa . Evaluasi usabi," Ekon. J. Tek. D A N Vol, Inform., vol. 6, no. 2, pp. 9-19, 2018.

[13] J. Nielsen, "10 usability heuristic for user interface design.," 2013.

[14] J. Nielsen and R. Molich, "Heuristic evaluation of user interfaces," Conf. Hum. Factors Comput. Syst. - Proc., no. April, pp. 249-256, 1990, doi: 10.1145/97243.97281.

[15] E. Purnamasari, H. Wijayanti, Y. Alqadri, D. A. Rahayu, and F. Y. Supomo, "Evaluasi Website JobsDB Mobile dengan Metode Usability Heuristic," Semin. Ilm. Nas. Komput. dan Sist. Intelejen, vol. 7, pp. 123-130, 2012.

[16] H. S. Sutedjo, S. Wignjosoebroto, and A. Rahman, "Perancangan web interface Institut Teknologi Sepuluh Nopember (ITS) dengan memperhatikan aspek usability,” J. Tek. ITS, vol. 1, no. 1, pp. 494-497, 2012.

[17] T. K. Ahsyar, Husna, and Syaifullah, "Evaluasi Usability Sistem Informasi Akademik SIAM Menggunakan Metode Heuristic Evaluation," Semin. Nas. Teknol. Informasi, Komun. dan Ind., vol. 11, no. November, pp. 163-170, 2019.

[18] H. Utomo, E. Muh, A. Jonemaro, and M. T. Ananta, "Perbandingan Usabilitas Aplikasi Taxi Online Android ( Grab-car dan Uber ) Menggunakan Unified Theory of Acceptance and Use of Technology ( UTAUT )," J. Pengemb. Teknol. Inf. dan Ilmu Komput. Vol., vol. 1, no. 12, pp. 1708-1717, 2017.

[19] T. K. Ahsyar and D. Afani, "Evaluasi Usability Website Berita Online Menggunakan Metode Heuristic Evaluation,” J. Ilm. Rekayasa dan Manaj. Sist. Inf., vol. 5, no. 1, p. 34, 2019, doi: 10.24014/rmsi.v5i1.7373.

[20] D. Rusvinasari, A. Setyanto, and M. R. Arief, “Analisis User Interface pada Aplikasi Mobile Pelaporan Online Menggunakan Heuristic Evaluation,” Respati, vol. XV, pp. 12-20, 2020, [Online]. Available: http://jti.respati.ac.id/index.php/jurnaljti/article/view/326.

[21] I. G. A. A. Diah Inrayani, I. P. A. Bayupati, and I. M. S. Putra, "Analisis Usability Aplikasi iBadung Menggunakan Heuristic Evaluation Method," J. Ilm. Merpati (Menara Penelit. Akad. Teknol. Informasi), vol. 8, no. 2, pp. 89-100, 2020.

[22] A. W. A. Wibowo, "Analisis Usabilitas Pada Aplikasi Mandiri Online," J@ti Undip J. Tek. Ind., vol. 15, no. 1, p. 11, 2020, doi: 10.14710/jati.15.1.11-19.

[23] D. Sulistyaningrum, H. Tolle, and ..., "Evaluasi dan Perbaikan User Experience Pada Aplikasi Mobile UB TV Dengan Metode Heuristic Evaluation dan Usability Testing," ... Teknol. Inf. dan ..., vol. 3, no. 7, pp. 6294-6302, 2019, [Online]. Available: http://j-ptiik.ub.ac.id/index.php/jptiik/article/download/5685/2701.

[24] R. Firmansyah, "Evaluasi Heuristik Pada Desain Interface Aplikasi My Indihome," Semin. Nas. Ilmu Pengetah. dan Teknol. Komput., pp. 69-INF.76, 2016, [Online]. Available: https://konferensi.nusamandiri.ac.id/prosiding/index.php/sniptek/article/view/19.

[25] S. I. Irwan, I. S. Sitanggang, and B. Mustafa, “Analisis Usabilitas Sistem Informasi Manajemen Penerimaan Koleksi Deposit Di Perpusnas Berdasarkan Pendekatan Evaluasi Heuristik," J. Pustak. Indones., vol. 14, no. 1, pp. 33-42, 2015.

[26] D. Sugiyono, Metode Penelitian Kuantitatif dan R \& D. Bandung, 2010. 